\title{
Teaching Design of "Properties of Sodium" based on the Core Literacy of Chemistry
}

\author{
Chengqi Sun \\ Shandong University, Weihai, China \\ scqdylan@163.com
}

\begin{abstract}
The learning of sodium and its chemical compounds are the beginning of systematic learning of elemental compounds in senior high school, and have a vital influence on senior high school chemistry learning. This paper is about the teaching design of the first class --the properties of sodium. Based on the five core qualities of chemistry, it adopts the method of situational teaching, gives prominence to the connection and transition among knowledge points, and sets up multiple experiments and group discussions to guide students to construct and form their thinking pattern in chemistry and scientific thinking methods.
\end{abstract}

Keywords: Teaching Design; Core Literacy of Chemistry; Sodium.

\section{Teaching Analysis}

\subsection{Analysis on Teaching Material}

This class is the first class of "Sodium and its Compounds" in the first section of the second chapter of the first required volume of chemistry in PEP edition high school textbooks. In the textbook, it explains the atomic structure of sodium, and guides students to learn the physical and chemical properties of sodium through experiments and inquiry activities, and expounds the application of its properties.

This section is about the first typical metal element to be learnt in high school, and the first step of systematic learning of inorganic element compounds. It has a vital impact on students' construction of methods and ideas for studying metals and also nonmetals and their compounds, and lays a foundation for later study of other element compounds, material structure and periodic law of elements. In addition, in the first chapter, students have already learned some basic and general knowledge, such as simple experimental operation, classification of substances, mutual transformation among substances containing the same elements, writing of electrolyte ionization and ion reaction equations, redox reaction and so on. In this lesson, the knowledge is made clear and application examples are provided, which is helpful for students to understand and consolidate relevant knowledge.

\subsection{Analysis of Students' Learning Situation}

(1) Knowledge level.

Students have already learned related knowledge of metals in junior high school, including the physical properties of some metals, the sequence table of metal activeness, and the reaction of some metals with oxygen, acid and salt, knowledge of atomic structure and simple experimental operation skills. All of the above are the basis for further systematic study of metals and their compounds in high school.

Students have already learned the classification of substances, ion reaction, redox reaction principle and other knowledge in senior high school. They should make use of the above knowledge to understand the properties and reactions of sodium in this class, and consolidate as well as deepen their understanding of related knowledge.

(2) Cognitive level.

At present, students' thinking mode is at the transition of changing from perceptual thinking pattern in junior high school to rational logical thinking needed in senior high school, and they already have a certain degree of chemical discipline ability. Through the study of the first chapter, students have 
preliminarily established a perspective of understanding the two substances and their changes, namely, substance categories and element valence states, which are very important for the later study of elemental compounds. However, students have not fully grasped the idea of understanding the properties of matter from the perspective of atomic structure and material composition and exploring through experiments, and may still use the perceptual thinking mode and existing experience to learn the related knowledge of sodium [1].

(3) Learning style.

Senior high school students are more interested in situational classroom, and most of them possess the visual learning style, and there are a few tactile and visual students too [2]. Therefore, using situational teaching strategy and multimedia teaching can introduce knowledge from perceptual experience in life, help students to observe photos and objects carefully, conduct experimental inquiry and sum up the information discovered by students themselves. Then teachers can explain the key knowledge points. This can make students with different learning styles all feel comfort in class while paying more attention to class content, and effectively improve classroom efficiency and students' listening quality [3].

\section{Teaching Objectives}

1). Understand the properties of sodium by learning its atomic structure, cultivate students to gain the concept of "structure determines properties, and properties determine application", and let students form the core literacy of macroscopic identification and microscopic analysis, as well as the awareness of model cognition [4-7].

2). Learn the chemical reactions and products of metallic sodium and oxygen under different conditions through experiments, gain profound understanding of the influences of various conditions on the process, phenomena and generated substances of chemical reactions, and form the core literacy of chemistry of the idea of changing and the thinking pattern of balancing.

3). Learn the reaction between sodium and water through experiments, predict and explore the reaction phenomena and products, and form the core literacy of evidential reasoning and model cognition.

4). Learn to take advantage of experiments to verify conjectures, understand the important steps and thinking mode of scientific research, and form the core literacy of scientific research and innovation consciousness.

5). By studying the properties of metallic sodium and understanding the application and preservation methods of sodium, form the core literacy of scientific attitude and social responsibility.

\section{Key and Difficult Points in Teaching}

Key points in teaching: (1) Understand the reaction of sodium and water as well as sodium and oxygen through experiments; (2) Analyze the essence of those reactions; (3) Construction of research ideas and methods of sodium.

Difficult points in teaching: (1) Exploratory experiment of reaction between sodium and water; (2) Influence of different reaction conditions on reaction phenomena and products of sodium and oxygen. 


\section{Teaching Process}

\begin{tabular}{|c|c|}
\hline $\begin{array}{l}\text { The world of sodium } \\
\text { (4 minutes) }\end{array}$ & - Introduction \& inspiration \\
\hline $\begin{array}{l}\text { What is sodium } \\
\text { (5 minutes) }\end{array}$ & $\begin{array}{l}\text {-Analyze the atomic structure of sodium and } \\
\text { explain the strong reduction of monomeric } \\
\text { sodium with the common valence state of } \\
\text { sodium elements. }\end{array}$ \\
\hline $\begin{array}{c}\text { Changeable sodium } \\
\text { (12 minutes) }\end{array}$ & $\begin{array}{c}\text { - Conduct experiments to explore the } \\
\text { different reaction phenomena and products } \\
\text { of sodium and oxygen under different } \\
\text { conditions. }\end{array}$ \\
\hline $\begin{array}{l}\text { Sodium \& water } \\
(13 \text { minutes })\end{array}$ & $\begin{array}{l}\text { - Learn how sodium reacts with water and } \\
\text { investigate the environment in which sodium } \\
\text { is preserved by conducting experiments. }\end{array}$ \\
\hline $\begin{array}{c}\text { Application of sodium } \\
\text { ( } 8 \text { minutes })\end{array}$ & $\begin{array}{l}\text {-Learn the reaction of sodium and copper- } \\
\text { sulfate solution as well as the replacement } \\
\text { reaction of sodium and molten salt through } \\
\text { experimental investigation. }\end{array}$ \\
\hline $\begin{array}{l}\text { Wonderful world of sodium } \\
(3 \text { minutes })\end{array}$ & $\begin{array}{l}\text { - Review the knowledge of this lesson, give } \\
\text { assignments, and preview the content of the } \\
\text { next lesson. }\end{array}$ \\
\hline
\end{tabular}

Fig 1. Schematic diagram of teaching process

(This class is 45 minutes in total)

Table 1. Class time distribution

\begin{tabular}{|c|c|c|c|}
\hline $\begin{array}{c}\text { Class } \\
\text { sessions }\end{array}$ & Teacher activities & Student activities & Design intention \\
\hline \multicolumn{4}{|c|}{ Session 1: The world of sodium (4 minutes). } \\
\hline $\begin{array}{l}\text { Situational } \\
\text { introduction }\end{array}$ & $\begin{array}{l}\text { [Use multimedia device to show a } \\
\text { video of report on sodium ion } \\
\text { battery] Sodium ion battery is a } \\
\text { hot research field at present. If it } \\
\text { can be applied in large scale in the } \\
\text { future, the battery field will enter } \\
\text { a new stage. } \\
\text { Sodium is an element that we are } \\
\text { familiar with. In junior high } \\
\text { school, we learned about sodium } \\
\text { chloride and sodium carbonate. In } \\
\text { our daily life, we can also see } \\
\text { many substances containing } \\
\text { sodium, such as salt, the sodium } \\
\text { chloride; and baking soda, the } \\
\text { sodium bicarbonate. [Use PPT to } \\
\text { show photos of the above } \\
\text { examples] }\end{array}$ & $\begin{array}{l}\text { Watch videos and photos, learn } \\
\text { about sodium ion batteries, } \\
\text { recall and think about the } \\
\text { compounds of sodium learned in } \\
\text { junior high school and the } \\
\text { application of sodium in life. }\end{array}$ & $\begin{array}{l}\text { Introduce scientific } \\
\text { research achievements } \\
\text { related to this lesson, } \\
\text { and expand students' } \\
\text { vision of chemistry. } \\
\text { Guide students to recall } \\
\text { the knowledge they } \\
\text { have learned and their } \\
\text { daily life experiences, } \\
\text { so as to introduce this } \\
\text { class's contents. }\end{array}$ \\
\hline Questioning & $\begin{array}{l}\text { We can find that both sodium ion } \\
\text { batteries and other examples are } \\
\text { the application of sodium } \\
\text { compounds. We are familiar with } \\
\text { sodium and its compounds, but } \\
\text { we are not so familiar with } \\
\text { metallic sodium in the form of }\end{array}$ & $\begin{array}{l}\text { Compare the application of } \\
\text { metallic sodium with other } \\
\text { metals, and think about the } \\
\text { reason why metallic sodium is } \\
\text { not common in life. }\end{array}$ & $\begin{array}{l}\text { The properties of } \\
\text { sodium are naturally } \\
\text { introduced by reflecting } \\
\text { on life experience. By } \\
\text { comparing it with other } \\
\text { metals, students are } \\
\text { guided to think about }\end{array}$ \\
\hline
\end{tabular}




\begin{tabular}{|c|c|c|c|}
\hline & $\begin{array}{l}\text { simple substance, because there is } \\
\text { no free sodium in nature. Metals } \\
\text { like iron, gold and silver can be } \\
\text { directly contacted in our lives. } \\
\text { Why? Why don't people use } \\
\text { sodium to make tableware or } \\
\text { ornaments? } \\
\text { [Use PPT to show photos of iron } \\
\text { tableware and gold and silver } \\
\text { jewelries] }\end{array}$ & & $\begin{array}{l}\text { the phenomena in life } \\
\text { and ask questions, } \\
\text { students' scientific } \\
\text { attitude towards things } \\
\text { are cultivated, their } \\
\text { awareness of actively } \\
\text { exploring problems are } \\
\text { enhanced, and students } \\
\text { can be concentrated on } \\
\text { the content of this } \\
\text { lesson. }\end{array}$ \\
\hline $\begin{array}{l}\text { Preliminary } \\
\text { perception }\end{array}$ & $\begin{array}{c}\text { We can use the chemistry } \\
\text { knowledge learnt to answer } \\
\text { questions found in our lives. } \\
\text { Please pay attention to the rank of } \\
\text { sodium, iron, silver and gold in } \\
\text { the metal activeness sequence } \\
\text { table, and answer the questions } \\
\text { raised. }\end{array}$ & $\begin{array}{l}\text { [Student's answer] The rank of } \\
\text { sodium is quite high, and it is } \\
\text { active, so it is difficult to exist } \\
\text { as a simple substance in life. }\end{array}$ & $\begin{array}{l}\text { Make students possess } \\
\text { preliminary } \\
\text { understanding of the } \\
\text { activity of sodium. }\end{array}$ \\
\hline \multicolumn{4}{|c|}{ Session 2: What is sodium (5 minutes). } \\
\hline $\begin{array}{c}\text { Student } \\
\text { activities }\end{array}$ & $\begin{array}{l}\text { The properties of substances are } \\
\text { determined by structure and can } \\
\text { be analyzed from the structure. } \\
\text { Use the knowledge learned in } \\
\text { junior high school, draw a } \\
\text { schematic diagram of the } \\
\text { structure of sodium atom and } \\
\text { answer the following questions. } \\
\text { [Use PPT to show questions] }\end{array}$ & $\begin{array}{l}\text { Draw the atomic structure and } \\
\text { answer the questions shown on } \\
\text { PPT: } \\
\text { There are___electrons in the } \\
\text { outermost layer of sodium, and } \\
\text { it is easy to (lose/get) } \\
\text { electrons. The simple substance } \\
\text { of sodium has____ (strong } \\
\text { reducibility/strong } \\
\text { oxidizability), and the valence } \\
\text { state of sodium element is__ } \\
\text { - }\end{array}$ & $\begin{array}{l}\text { Through the atomic } \\
\text { structure, we can learn } \\
\text { the strong reducibility } \\
\text { of sodium and the } \\
\text { common valence state } \\
\text { of sodium. This can } \\
\text { guide students to } \\
\text { analyze properties from } \\
\text { structure, and cultivate } \\
\text { their chemistry concept } \\
\text { that the structure } \\
\text { determines properties. } \\
\text { This provides a } \\
\text { knowledge base for } \\
\text { later learning of the } \\
\text { reactions between } \\
\text { sodium and various } \\
\text { substances. }\end{array}$ \\
\hline Transition & \multicolumn{3}{|c|}{$\begin{array}{l}\text { The atomic structure of sodium can explain the relatively high activeness of sodium, which is } \\
\text { consistent with our conclusion from the metal activeness sequence table. How active is sodium? } \\
\text { We can intuitively feel the strong reducibility of sodium through experiments. }\end{array}$} \\
\hline \multicolumn{4}{|c|}{ Session 3: Changeable sodium (12 minutes). } \\
\hline $\begin{array}{c}\text { Exploration } \\
\text { by activity }\end{array}$ & $\begin{array}{l}\text { Let's first take a look at what } \\
\text { happens to metallic sodium in the } \\
\text { air. [Use PPT to show steps and } \\
\text { precautions of the experiment] }\end{array}$ & $\begin{array}{l}\text { (1) Take a small piece of } \\
\text { sodium with tweezer, sip up } \\
\text { liquid on its surface with filter } \\
\text { paper, and observe the surface } \\
\text { of sodium; (2) Cut sodium with } \\
\text { a knife by one side on glass } \\
\text { sheet, feel the degree of } \\
\text { hardness of sodium, and observe } \\
\text { the color and luster of the cut } \\
\text { surface; (3) Pay attention to the } \\
\text { changes in the cut surface; (4) } \\
\text { All the remaining sodium is put } \\
\text { back into the original bottle. } \\
\text { [Group discussion on the above } \\
\text { phenomena] }\end{array}$ & $\begin{array}{c}\text { Cultivate students' } \\
\text { experimental } \\
\text { observation ability and } \\
\text { basic operation ability. }\end{array}$ \\
\hline
\end{tabular}




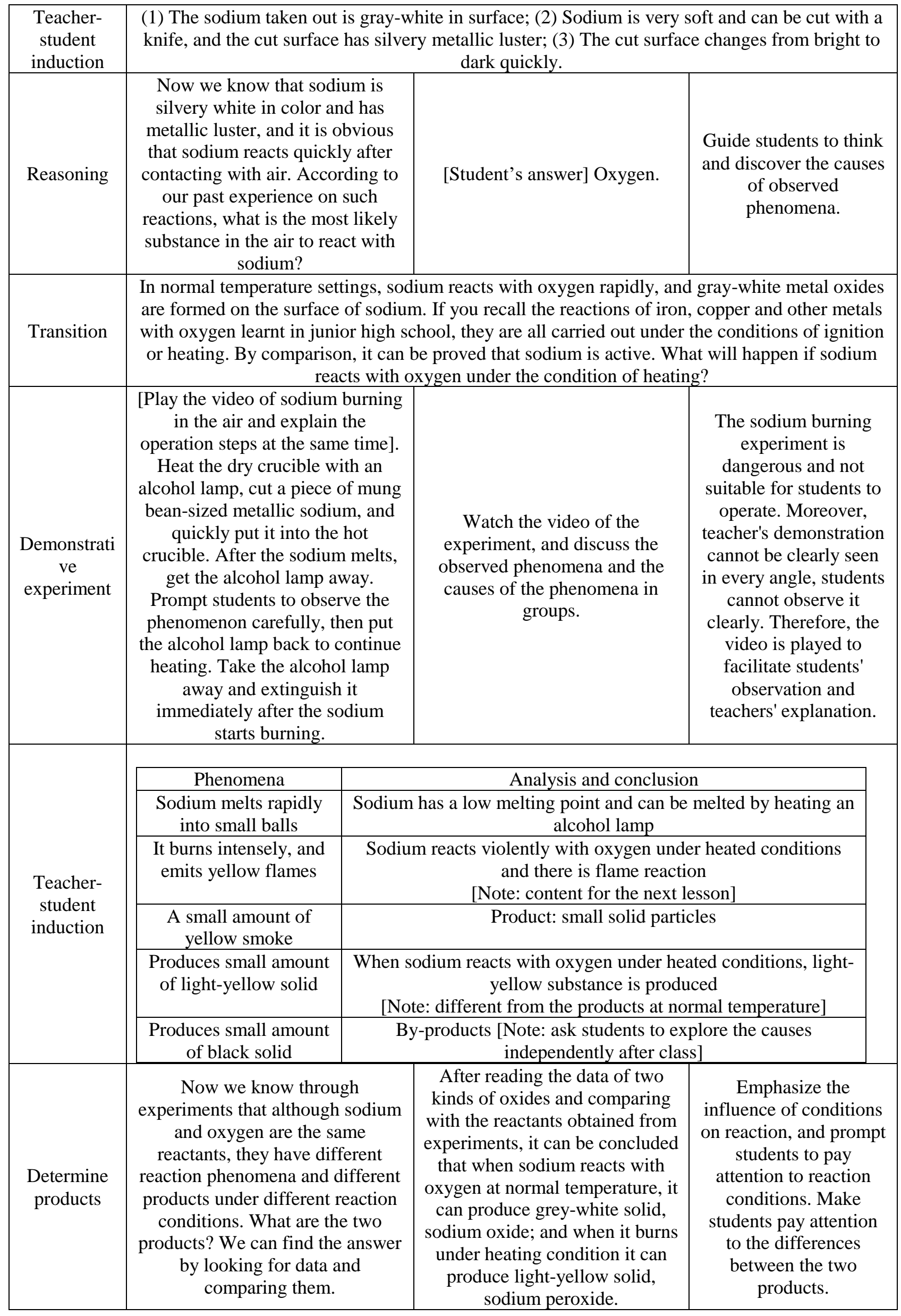




\begin{tabular}{|c|c|c|c|}
\hline & $\begin{array}{l}\text { [Show photos and data of sodium } \\
\text { oxide and sodium peroxide] } \\
\text { Sodium oxide, Na2O: grey-white } \\
\text { solid } \\
\text { Sodium peroxide, Na2O2: light- } \\
\text { yellow solid }\end{array}$ & & $\begin{array}{l}\text { Cultivate students' } \\
\text { ability to actively } \\
\text { collect and analyze } \\
\text { evidence and find } \\
\text { answers in scientific } \\
\text { exploration. }\end{array}$ \\
\hline $\begin{array}{l}\text { Learn about } \\
\text { sodium } \\
\text { peroxide }\end{array}$ & $\begin{array}{l}\text { We are unfamiliar with sodium } \\
\text { peroxide, because the valence } \\
\text { state of oxygen is not the familiar } \\
-2 \text { valence, but we have learned a } \\
\text { similar peroxide-hydrogen } \\
\text { peroxide in junior high school } \\
\text { when oxygen is - } 1 \text { valence, } \\
\text { hydrogen peroxide. } \\
\text { [Write the followings on the } \\
\text { blackboard] Na2O2, } \mathrm{H} 2 \mathrm{O} 2 \text {, and } \\
\text { give the valence state of oxygen. }\end{array}$ & $\begin{array}{l}\text { Recall hydrogen peroxide, } \\
\text { understand peroxides by } \\
\text { recalling it, and compare it with } \\
\text { sodium peroxide. }\end{array}$ & $\begin{array}{l}\text { Explain sodium } \\
\text { peroxide by analogy } \\
\text { with hydrogen } \\
\text { peroxide, which is } \\
\text { familiar to students. } \\
\text { This is helpful for } \\
\text { students to understand } \\
\text { and remember sodium } \\
\text { peroxide. }\end{array}$ \\
\hline $\begin{array}{l}\text { Chemical } \\
\text { equation }\end{array}$ & $\begin{array}{l}\text { We have determined the reaction } \\
\text { conditions and products. Please } \\
\text { write the chemical equations of } \\
\text { the two reactions. }\end{array}$ & $\begin{array}{c}\text { Write down the chemical } \\
\text { equations of two reactions: } \\
4 \mathrm{Na}+\mathrm{O}_{2}=2 \mathrm{Na}_{2} \mathrm{O}, 2 \mathrm{Na}+\mathrm{O}_{2} \stackrel{\Delta}{=} \\
\mathrm{Na}_{2} \mathrm{O}_{2}\end{array}$ & $\begin{array}{c}\text { Exercise students' } \\
\text { ability of writing } \\
\text { chemical equations and } \\
\text { balancing. }\end{array}$ \\
\hline Summary & $\begin{array}{l}\text { When there is redox reaction betw } \\
\text { (1) at normal temperature, sodium } \\
\text { (2) when heated, sodium reacts vi }\end{array}$ & $\begin{array}{l}\text { sodium and oxygen, with sodiv } \\
\text { oxygen as oxidant: } \\
\text { n easily react with oxygen } 4 \mathrm{Na}+0 \\
\text { ently with oxygen } 2 \mathrm{Na}^{2} \mathrm{O}_{2}\end{array}$ & $\begin{array}{l}\mathrm{m} \text { as reducing agent and } \\
=2 \mathrm{Na}_{2} \mathrm{O} \text { (white solid). } \\
{ }_{2} \mathrm{O}_{2} \text { (light- yellow solid). }\end{array}$ \\
\hline Supplement & $\begin{array}{l}\text { Sodium is a metallic simple } \\
\text { substance, which can react with } \\
\text { non-metallic simple substances } \\
\text { such as oxygen. We learned about } \\
\text { the reaction between sodium and } \\
\text { chlorine in the oxidation- } \\
\text { reduction reaction in Section } 3 \text { of } \\
\text { Chapter 1. Please write down the } \\
\text { reaction equation, and write down } \\
\text { the chemical equation of the } \\
\text { reaction between sodium and } \\
\text { sulfur by analogy. }\end{array}$ & $\begin{array}{l}\text { Write down the equations: } \\
\qquad \begin{array}{c}2 \mathrm{Na}+\mathrm{Cl}_{2} \triangleq \\
2 \mathrm{Na}+\mathrm{S} \triangleq \mathrm{Na}_{2} \mathrm{~S}\end{array}\end{array}$ & $\begin{array}{c}\text { Supplement necessary } \\
\text { knowledge points and } \\
\text { review previously learnt } \\
\text { knowledge. From the } \\
\text { reaction of sodium and } \\
\text { oxygen to the reaction } \\
\text { of metal and nonmetal, } \\
\text { it lays a foundation for } \\
\text { the learning of other } \\
\text { metals. }\end{array}$ \\
\hline \multicolumn{4}{|c|}{ Session 4: Sodium \& water (13 minutes). } \\
\hline Transition & \multicolumn{3}{|c|}{$\begin{array}{l}\text { Through the previous two experiments, we can learn that sodium is very active, and metallic } \\
\text { sodium is very easy to react with oxygen in the air. Therefore, how to preserve sodium is an } \\
\text { important issue. During the first experiment, students will find that sodium is not directly placed } \\
\text { in reagent bottle, but stored in liquid to isolate the air. So what is the liquid in the bottle? }\end{array}$} \\
\hline Questioning & \multicolumn{3}{|c|}{$\begin{array}{l}\text { In junior high school, we have also learned a substance that can't be directly exposed to the air -- } \\
\text { - white phosphorus, which is stored in water. Can sodium metal be stored in water like white } \\
\text { phosphorus to isolate the air? }\end{array}$} \\
\hline $\begin{array}{l}\text { Exploration } \\
\text { by activity }\end{array}$ & $\begin{array}{l}\text { Let's take a look at what happens } \\
\text { to sodium in water through } \\
\text { experiments, and pay attention to } \\
\text { the position, state, movement, size } \\
\text { change and sound of sodium in } \\
\text { water. } \\
\text { [Use PPT to show steps and } \\
\text { precautions of the experiment] }\end{array}$ & $\begin{array}{l}\text { Add one-third volume of water } \\
\text { into the beaker, take out a piece } \\
\text { of sodium, absorb kerosene } \\
\text { attached to its surface with filter } \\
\text { paper, cut a piece of mung-bean } \\
\text { size sodium, carefully put it into } \\
\text { the water, immediately cover the } \\
\text { beaker mouth with glass sheet, } \\
\text { and put the remaining sodium } \\
\text { back into the original bottle. } \\
\text { During the operation, carefully } \\
\text { observe the phenomena, }\end{array}$ & $\begin{array}{c}\text { Cultivate students' } \\
\text { experimental operation } \\
\text { skills and POE } \\
\text { strategies. Guide } \\
\text { students to obtain } \\
\text { evidence and analyze it } \\
\text { through experiments, so } \\
\text { as to provide solutions } \\
\text { to problems. }\end{array}$ \\
\hline
\end{tabular}




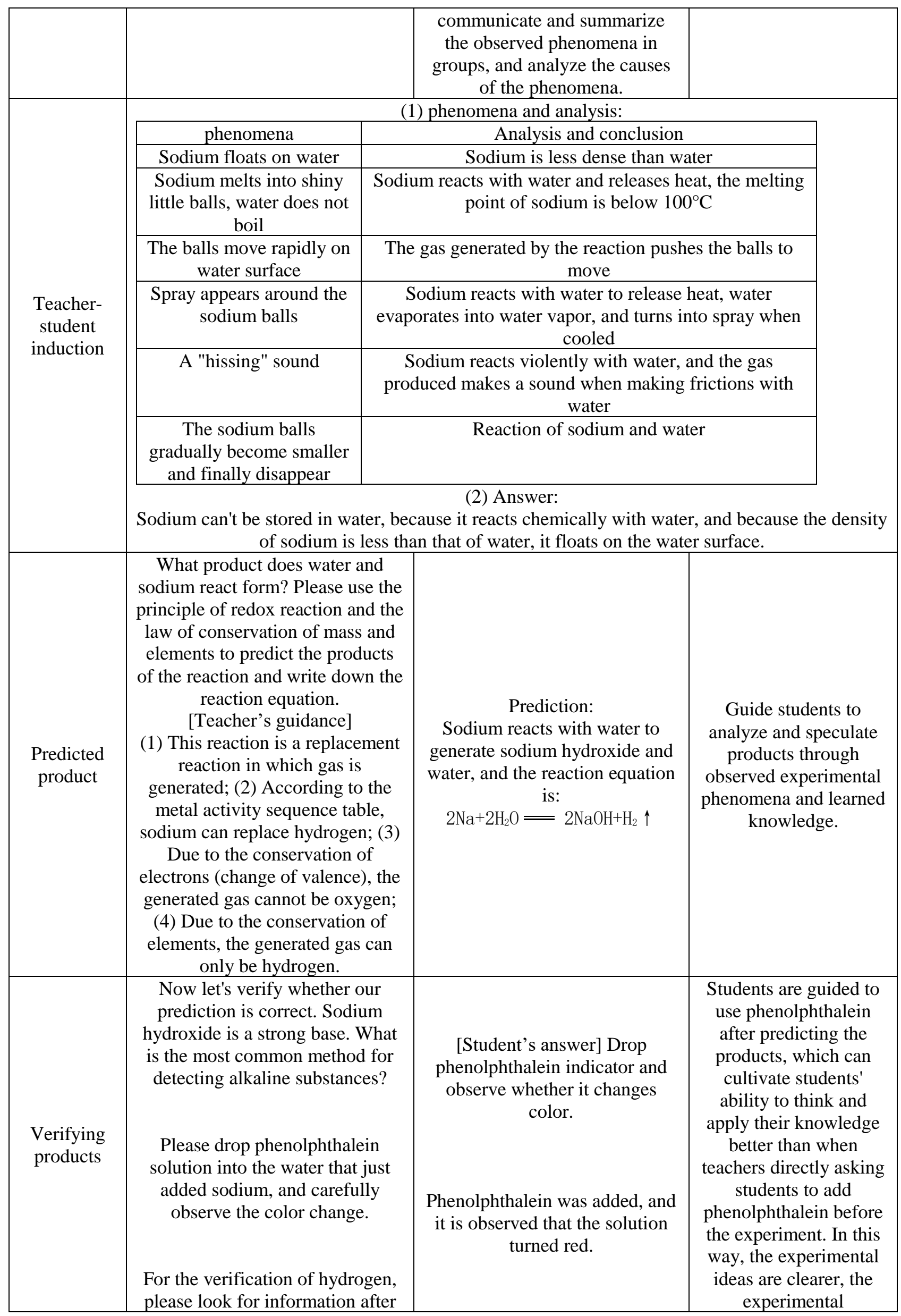




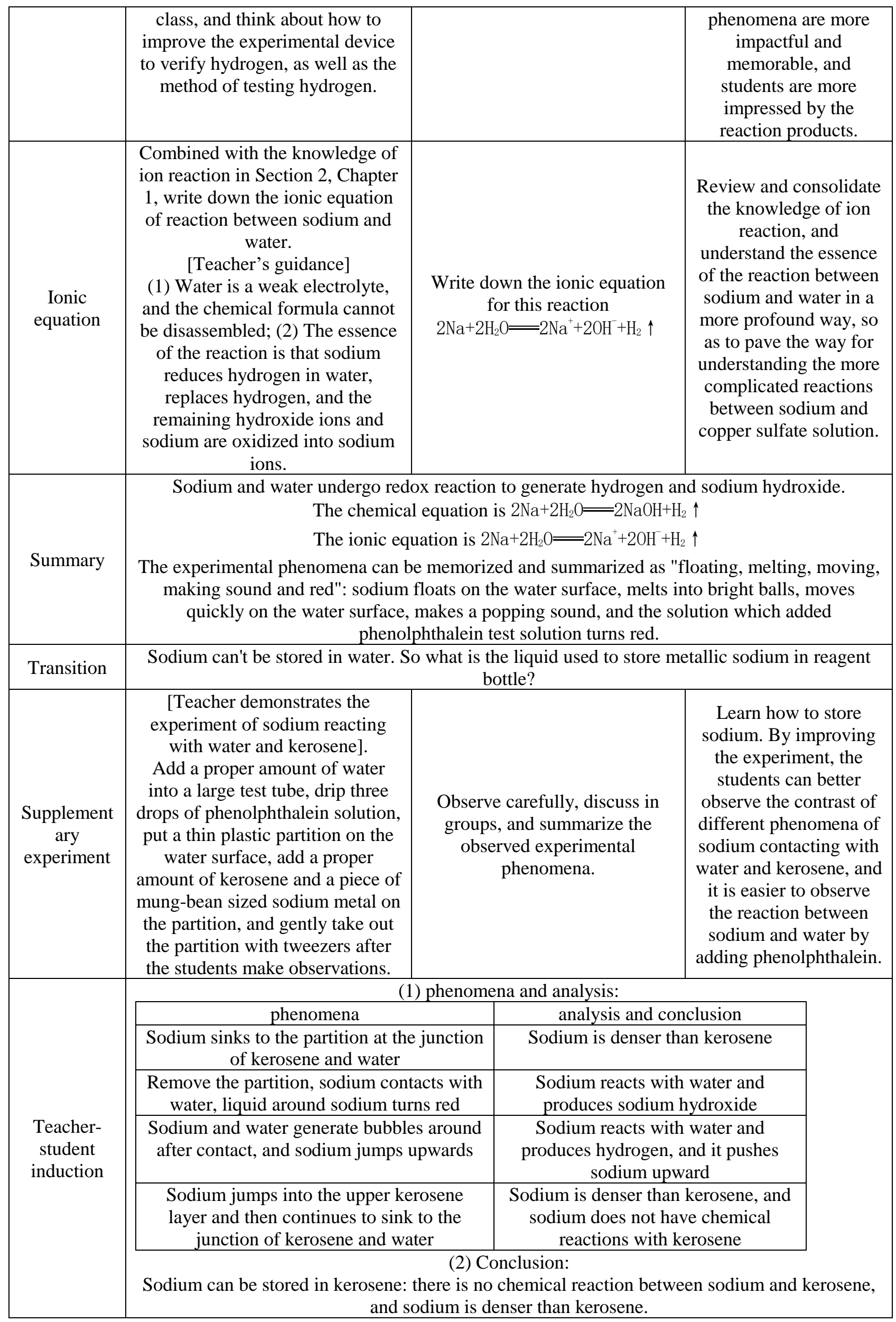


Volume 3 (2021)

\begin{tabular}{|c|c|c|c|}
\hline Summary & \multicolumn{3}{|c|}{$\begin{array}{l}\text { In the laboratory, sodium is usually stored in reagent bottle containing kerosene or paraffin oil to } \\
\text { isolate the air so as to prevent sodium from contacting oxygen and water in the air and trigger } \\
\text { chemical reaction. }\end{array}$} \\
\hline $\begin{array}{l}\text { Knowledge } \\
\text { application }\end{array}$ & $\begin{array}{l}\text { By reflecting on what you have } \\
\text { just learned, please think about } \\
\text { how to put out the fire when } \\
\text { sodium catches fire. Can water be } \\
\text { used to extinguish the fire? Why? } \\
\text { [Teacher's explanation] } \\
\text { When sodium is on fire, it can't be } \\
\text { extinguished by water or foam } \\
\text { extinguisher, because sodium } \\
\text { reacts violently with water, and } \\
\text { the sodium peroxide produced by } \\
\text { burning sodium will release } \\
\text { oxygen when it reacts with carbon } \\
\text { dioxide and water (this will be } \\
\text { learnt in the next class), so it is } \\
\text { necessary to put out the fire with } \\
\quad \text { dry sand. } \\
\text { In addition, by using the reaction } \\
\text { of sodium and water, sodium can } \\
\text { be used as a strong water remover } \\
\text { in industrial production to remove } \\
\text { trace water in organic matter. }\end{array}$ & $\begin{array}{l}\text { [Student's answer] We can't put } \\
\text { out the fire with water, because } \\
\text { the reaction between sodium } \\
\text { and water will make the fire } \\
\text { bigger. }\end{array}$ & $\begin{array}{l}\text { By asking questions, } \\
\text { students are guided to } \\
\text { use their knowledge to } \\
\text { solve practical } \\
\text { problems that may be } \\
\text { encountered in } \\
\text { production and life, } \\
\text { consolidate basic } \\
\text { knowledge, cultivate } \\
\text { safety awareness and } \\
\text { learn to apply chemical } \\
\text { knowledge to social } \\
\text { practice. }\end{array}$ \\
\hline \multicolumn{4}{|c|}{ Session 5: Application of sodium (8 minutes). } \\
\hline & \multicolumn{3}{|c|}{ After learning the properties of sodium, let's take a look at the application of sodium. } \\
\hline Questioning & \multicolumn{3}{|c|}{$\begin{array}{l}\text { There is a saying in Chinese ancient books, "add iron into copper sulfate solution, copper will } \\
\text { appear", which describes how to get copper through replacement reaction. This reaction has } \\
\text { been studied in the first chapter. Iron can react with copper sulfate solution to replace copper, } \\
\text { because iron is more reducible than copper. In that case, sodium is more reducible than iron, can } \\
\text { copper be replaced too? }\end{array}$} \\
\hline $\begin{array}{c}\text { Predicting } \\
\text { experimenta } \\
1 \\
\text { phenomena }\end{array}$ & $\begin{array}{l}\text { Please think and predict what will } \\
\text { happen when sodium metal is put } \\
\text { into copper sulfate solution. }\end{array}$ & $\begin{array}{l}\text { Predicting experimental } \\
\text { phenomena: (1) Sodium } \\
\text { replaces copper: red solid is } \\
\text { formed; (2) Sodium reacts with } \\
\text { water to generate sodium } \\
\text { hydroxide, and sodium } \\
\text { hydroxide reacts with copper } \\
\text { sulfate to generate copper } \\
\text { hydroxide: blue precipitate is } \\
\text { generated. }\end{array}$ & \multirow{2}{*}{$\begin{array}{l}\text { Compare the reactions } \\
\text { of copper and copper } \\
\text { sulfate solution and iron } \\
\text { and copper sulfate } \\
\text { solution respectively, } \\
\text { students' cognitive } \\
\text { conflict may arouse. } \\
\text { Break the mindset of } \\
\text { students' perception that } \\
\text { replacement reaction } \\
\text { only happen according } \\
\text { to the metal activity } \\
\text { sequence table, and let } \\
\text { students gain a clearer } \\
\text { and more } \\
\text { comprehensive } \\
\text { understanding of the } \\
\text { activeness of sodium. }\end{array}$} \\
\hline $\begin{array}{l}\text { Activity } \\
\text { inquiry }\end{array}$ & $\begin{array}{l}\text { Now, please verify whether the } \\
\text { prediction is correct through } \\
\quad \text { experiments. } \\
\text { [PPT shows experimental steps } \\
\text { and precautions] }\end{array}$ & $\begin{array}{l}\text { Group experiment, add one- } \\
\text { third volume of copper sulfate } \\
\text { solution into a beaker, cut out a } \\
\text { piece of sodium as large as } \\
\text { mung bean, absorb kerosene } \\
\text { attached to the surface with } \\
\text { filter paper, put it into the } \\
\text { solution, and immediately cover } \\
\text { the beaker mouth with glass } \\
\text { sheet. } \\
\text { During the operation, observe } \\
\text { the experimental phenomena } \\
\text { carefully, and discuss and } \\
\text { communicate in groups. }\end{array}$ & \\
\hline
\end{tabular}


Volume 3 (2021)

\begin{tabular}{|c|c|c|c|}
\hline Induction & \multicolumn{3}{|c|}{$\begin{array}{l}\text { Sodium floats on the water surface, melts into small bright balls, move rapidly on the water } \\
\text { surface, and there is a popping sound, resulting in blue precipitation. }\end{array}$} \\
\hline $\begin{array}{l}\text { Chemical } \\
\text { equation }\end{array}$ & $\begin{array}{l}\text { Experiments have proved that } \\
\text { sodium reacts with water, but } \\
\text { copper is not generated, and blue } \\
\text { precipitate of copper hydroxide is } \\
\text { formed. Please write down the } \\
\text { reaction equation of sodium in } \\
\text { copper sulfate solution. }\end{array}$ & $\begin{array}{l}\text { Write down chemical equations: } \\
\qquad \begin{array}{l}2 \mathrm{Na}+2 \mathrm{H}_{2} \mathrm{O}=2 \mathrm{NaOH}+\mathrm{H}_{2} \uparrow \\
2 \mathrm{NaOH}+\mathrm{CuSO}_{4}=\mathrm{Cu}(\mathrm{OH})_{2} \downarrow \\
+\mathrm{Na}_{2} \mathrm{SO}_{4}\end{array}\end{array}$ & $\begin{array}{l}\text { Practice writing } \\
\text { equations. }\end{array}$ \\
\hline $\begin{array}{l}\text { Ionic } \\
\text { equation }\end{array}$ & $\begin{array}{l}\text { Please reflect on the knowledge of } \\
\text { ion reaction, and synthesize two } \\
\text { chemical equations into one ionic } \\
\text { equation. Pay attention to } \\
\text { substances that can be split or } \\
\text { omitted. } \\
\text { The essence of the reaction can be } \\
\text { understood more clearly by } \\
\text { learning ionic equation. The } \\
\text { reaction between sodium and } \\
\text { water generates hydrogen, and the } \\
\text { remaining hydroxide ions } \\
\text { combine with copper ions in } \\
\text { copper sulfate solution to form } \\
\text { copper hydroxide precipitate. }\end{array}$ & $\begin{array}{c}2 \mathrm{Na}+2 \mathrm{H}_{2} \mathrm{O}+\mathrm{Cu}^{2+}=2 \mathrm{Na}^{+}+ \\
\mathrm{Cu}(\mathrm{OH})_{2} \downarrow+\mathrm{H}_{2} \uparrow\end{array}$ & $\begin{array}{l}\text { Review the knowledge } \\
\text { of ion reaction and give } \\
\text { a concrete example to } \\
\text { understand the essence } \\
\text { of the reaction, so that } \\
\text { students can understand } \\
\text { the knowledge more } \\
\text { thoroughly. }\end{array}$ \\
\hline $\begin{array}{l}\text { Teacher's } \\
\text { explanation }\end{array}$ & \multicolumn{3}{|c|}{$\begin{array}{l}\text { Sodium is different from metallic elements like iron, it is easy to react with water. In alkali and } \\
\text { salt solutions, it should be considered that sodium reacts with water to generate sodium } \\
\text { hydroxide first, and only in acid with more hydrogen ions does the replacement reaction take } \\
\text { place, replacing hydrogen ions with hydrogen. }\end{array}$} \\
\hline $\begin{array}{l}\text { Smelting } \\
\text { metal by } \\
\text { sodium }\end{array}$ & $\begin{array}{l}\text { So is sodium incapable of } \\
\text { smelting metals? Actually, it is } \\
\text { possible. Please guess, besides the } \\
\text { solution, what other conditions } \\
\text { are conducive to the reaction? } \\
\text { Titanium in titanium alloy, which } \\
\text { is important in aerospace and } \\
\text { aviation, is generated by sodium } \\
\text { and molten titanium tetrachloride } \\
\text { through replacement reaction. } \\
\text { Please write down the chemical } \\
\text { equation of the reaction according } \\
\text { to the description. }\end{array}$ & $\begin{array}{c}\text { Write down the reaction } \\
\text { equation for smelting titanium } \\
\text { by sodium. } \\
4 \mathrm{Na}+\mathrm{TiCl}_{4}(\mathrm{~mol} \text { ten }) \\
\text { high temperature } \\
\end{array}$ & $\begin{array}{l}\text { Supplement necessary } \\
\text { knowledge points to let } \\
\text { students understand the } \\
\text { application of sodium. }\end{array}$ \\
\hline
\end{tabular}

Session 6: Wonderful world of sodium (3 minutes).

Finally, let's sort out the content of this class.

(1) Physical properties of sodium: silvery white solid with metallic luster, with low hardness, lower density than water, higher density than kerosene or paraffin oil, and lower melting point than $100^{\circ} \mathrm{C}$.

Teacherstudent induction
(2) Chemical properties of sodium: strong reducibility.

(1) Reaction with oxygen: $4 \mathrm{Na}+\mathrm{O}_{2}=2 \mathrm{Na}_{2} \mathrm{O}, 2 \mathrm{Na}+\mathrm{O}_{2} \stackrel{\Delta}{=} \mathrm{Na}_{2} \mathrm{O}_{2}$

(2) Reaction with other nonmetallic elements: $2 \mathrm{Na}+\mathrm{Cl}_{2} \stackrel{\Delta}{=} 2 \mathrm{NaCl}, 2 \mathrm{Na}+\mathrm{S}=\stackrel{\Delta}{=} \mathrm{Na}_{2} \mathrm{~S}$

(3) Reaction with water: $2 \mathrm{Na}+2 \mathrm{H}_{2} \mathrm{O}=2 \mathrm{NaOH}+\mathrm{H}_{2} \uparrow$

(4) In the copper sulfate solution: $2 \mathrm{Na}+2 \mathrm{H}_{2} \mathrm{O}+\mathrm{Cu}^{2+}=2 \mathrm{Na}^{+}+\mathrm{Cu}(\mathrm{OH})_{2} \downarrow+\mathrm{H}_{2} \uparrow$

(5) Smelting titanium by sodium: $4 \mathrm{Na}^{-} \mathrm{TiCl}_{4}($ molten $) \stackrel{\text { high temperature }}{=} \mathrm{Ti}+4 \mathrm{NaCl}$ 
Volume 3 (2021)

\begin{tabular}{|l|c|}
\hline $\begin{array}{l}\text { Concluding } \\
\text { remarks \& } \\
\text { assignment }\end{array}$ & $\begin{array}{c}\text { In this class, we started the exploration of elemental compounds, and learned various kinds of } \\
\text { interesting properties and applications of metallic sodium. Now we are no longer unfamiliar to } \\
\text { sodium the simple substance. In this lesson, we learnt that metallic sodium cannot be stored in } \\
\text { the air, so what will happen if sodium is stored in the air for a long time? What substance will it } \\
\text { eventually become? Please preview the content of the next section---sodium compounds after } \\
\text { class, and reflect on the knowledge learned in this class to find out the key to this problem. For } \\
\text { the exploration of sodium, we will continue in the next class. }\end{array}$ \\
\hline
\end{tabular}

\section{Blackboard Writing Design}

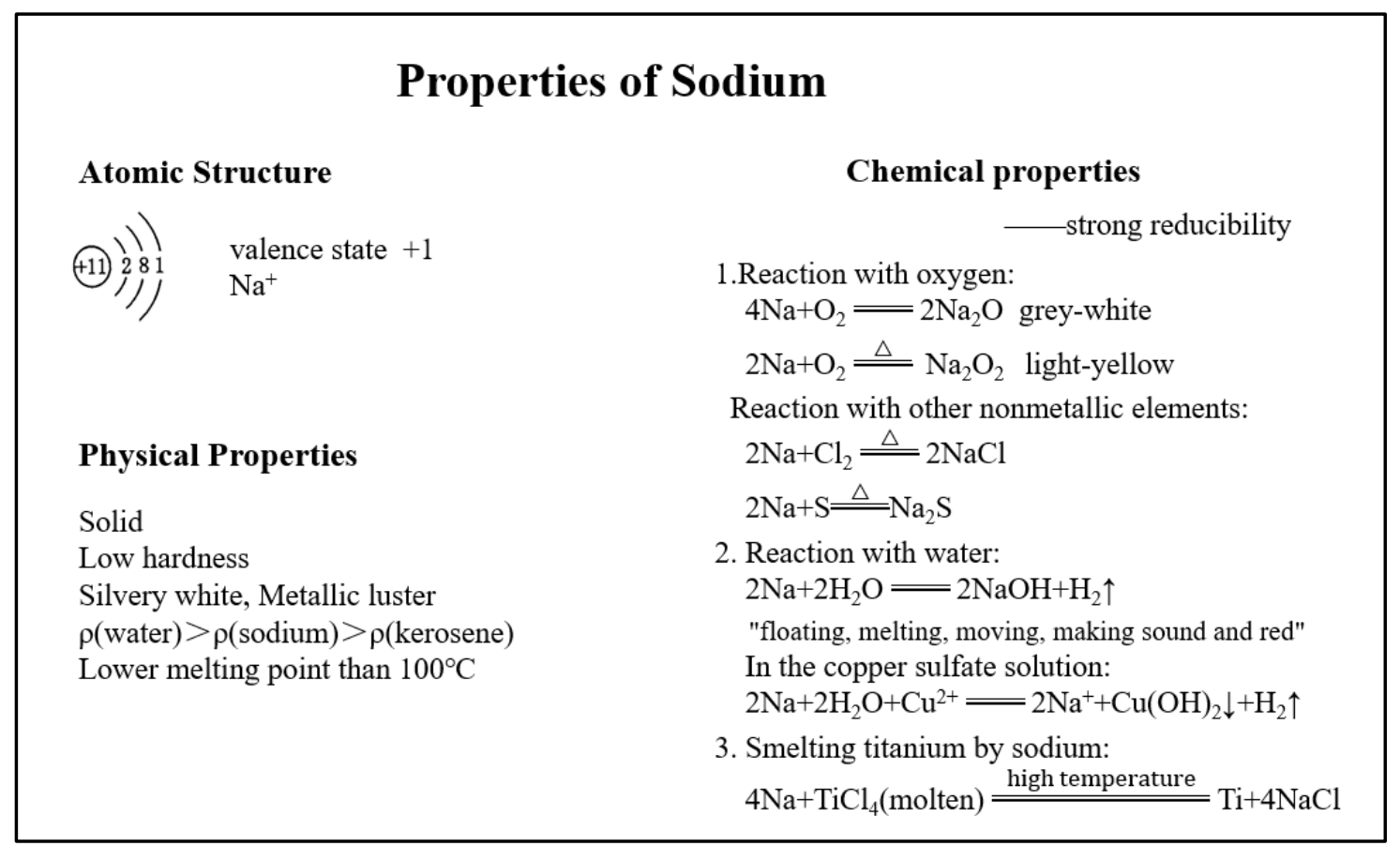

Fig 2. Properties of sodium

\section{Teaching Reflection}

1). Use sodium ion battery, the current hot research field related to class content, as the introduction of new course, and expand students' scientific vision by using multimedia. Classroom knowledge points (activeness of sodium) are embodied and introduced through life experience (the application of simple sodium has never been seen in life), which enhances students' awareness of applying the learned chemistry knowledge in daily life. By attracting students' attention through the introduction of new course, students can realize the significance and use of the learned knowledge before learning new knowledge, and actively learn new knowledge instead of being forced to accept it, which is conducive to students' understanding and mastery of knowledge, and can help students form the core discipline literacy of scientific attitude and social responsibility.

2 ). The whole class is carried out basing on the activeness of sodium, and a learning scenario is set, in which the old knowledge learned in junior middle school and daily life experience can help students feel the activeness of sodium, and the atomic structure of sodium is analyzed and recognized. Sodium's activeness is explored and verified by experiments done by classroom grouping. Then, combined with the knowledge learned in this class, students can reflect on the practical application of activeness, and the teaching sequence is in line with the thinking sequence. The teaching of new knowledge is inspired by existing experience and guides students to think, which is in line with the theory of zone of proximal development. It is conducive to the cultivation of students' scientific thinking ability, the subsequent study of other elements and compounds, and the formation of the core literacy of scientific inquiry and innovative consciousness. 
Volume 3 (2021)

3). Several organized experimental operations and observing experiments in class reflect the characteristics of chemistry discipline, and make students more impressed by the reactions they have learned. The setting of cooperative inquiry and group discussion is beneficial to students' formation of the core literacy of chemistry discipline. In the reaction experiment of sodium and water, the order of adding sodium and phenolphthalein was adjusted, and phenolphthalein was added after the reaction, leaving students with some room for thinking. In the reaction experiment of sodium, water and kerosene, the use of improved new experimental instruments is more conducive to the experiment and observation, and reflects the innovation and inquiry consciousness that learning chemistry should have.

4). At the end of the class, thinking assignments are arranged, and the reactions and final products of sodium placed in the air for a long time involve many knowledge points such as the reaction of sodium and oxygen learnt in this class, the reaction of sodium hydroxide and carbon dioxide learnt in junior high school, and the reaction of sodium oxide and water to be learnt in the next class, so that students can not only recall the learnt knowledge in junior high school, review and consolidate the new knowledge in this class, but also preview the contents of the next class, which will be conducive to the smooth and efficient progress of the next class and cultivate students' awareness and ability of autonomous learning.

\section{References}

[1] Wang Xue, Zheng Minghua. Teaching Design of "Exploring the Properties of Sodium Metallic" [J]. Examination Weekly, 2018(80):159-160.

[2] Wu Huiling. Investigation on Learning Styles of Senior High School Students and Their Teaching Practice [D]. Central China Normal University, 2011.

[3] Liang Danfeng. On Senior High School Physics Learning Style and Teaching Students in Accordance with Their Aptitude [J]. Examination Questions and Research, 2020(31):5-6.

[4] Ding Wei, Sun Angui. Experimental Study on Reaction Products of Sodium and Copper-Bath [J]. Chemistry Teaching, 2017(08):55-58+72.

[5] Dang Bowen. Teaching Design of "Properties of Sodium" [J]. Reference of Chemistry Teaching in Middle Schools, 2018(24):37-39.

[6] Hao Zhongqian, Yan Chenlu, Zhang Yong. Promoting the Construction of Chemistry Thinking Pattern in Classroom with Effective Questions --Taking "Properties and Application of Sodium Metallic" as An Example [J]. Reference of Chemistry Teaching in Middle Schools, 2021(06):27-28.

[7] Wang Baoqiang, Lu Guangjie, Wang Yinxing, Liu Fangyun. The Teaching Design of "Properties and Application of Metallic Sodium" Based on the Integration of Situation and Knowledge [J]. Chemistry Education (English/Chinese), 2019,40(01):23-26. 